\title{
Engineering Design Professional Development as a Mechanism for Changing Science Teachers' Beliefs (Fundamental)
}

\section{Prof. Tamara J. Moore, Purdue University, West Lafayette}

Tamara J. Moore, Ph.D., is an Associate Professor in the School of Engineering Education and Director of STEM Integration in the INSPIRE Institute at Purdue University. Dr. Moore's research is centered on the integration of STEM concepts in K-12 and postsecondary classrooms in order to help students make connections among the STEM disciplines and achieve deep understanding. Her work focuses on defining STEM integration and investigating its power for student learning. Tamara Moore received an NSF Early CAREER award in 2010 and a Presidential Early Career Award for Scientists and Engineers (PECASE) in 2012.

\section{Siddika Selcen Guzey, Purdue University, West Lafayette}

Dr. Guzey is an assistant professor of science education at Purdue University. Her research and teaching focus on integrated STEM Education.

Amanda C. Johnston, Purdue University, West Lafayette

Amanda Johnston is a graduate student in engineering education at Purdue University.

Mr. Murat Akarsu, Purdue University, West Lafayette

Murat Akarsu is a fifth-year Ph.D. student in the Mathematics Education interested in pre-service teachers' understanding of mathematics and geometry and STEM integration. Prior to arriving at Purdue University, he earned a master's degree in the department of mathematics at the University of Cincinnati in the USA. He is currently writing a dissertation on the pre-service teachers' understanding of geometric reflections in the USA. His dissertation explores pre-service secondary mathematics teachers' motion and mapping views and contributes to current research by offering insights into the development of an understanding of geometric reflection. He is also working as a research assistant in Engineering Education. His work is focused on student learning and interest engineering design to teach engineering, science, and mathematics.

\section{Peter Wesley Odom, Purdue University, West Lafayette}

Wesley is a PhD student in Engineering Education at Purdue University. His primary research interests surround assessment technologies, the psychology of student learning of STEM concepts, and international community development.

\section{Dr. Maurina Loren Aranda, Purdue University, West Lafayette}

Dr. Maurina Aranda recently obtained a PhD in the Biological Sciences at Purdue University, and through this background in science, her interests in education span a variety of fields. Mainly, Dr. Aranda's research interests include cellular biology education and STEM education. With these interests in mind, her work focuses on how students conceptualize cellular biology, their discourse practices as they enact science and engineering, and the views of both teachers and students as they enact and complete interdisciplinary curricula.

\section{Mr. Richard Lie, Purdue University, West Lafayette}

Richard Lie is a graduate student in the Department of Biological Sciences and graduate research assistant in the School of Engineering of Education at Purdue University. He received his BS/MS in Biology from the University of California, San Diego. His interests include usage of primary literature in undergraduate biology courses, STEM integration, and science process skills. 


\section{Engineering Design Professional Development as a Mechanism for Changing Science Teachers' Beliefs (Fundamental)}

Teachers should adopt effective pedagogical approaches in order to maximize student learning. The beliefs of teachers about instructional practice are an important construct in determining what and how they teach. This is especially important in light of recent reform efforts at the K-12 level to integrate engineering design into science curricula. Investigation into the area of engineering design-based STEM integration is necessary, as teachers are unfamiliar with engineering and are being asked to incorporate engineering into their teaching mid-career. Engineering integration requires that teachers teach in a student-centered manner.

This study investigates the change in teachers' beliefs about teaching, learning, and effective engineering design-based STEM integration instruction in upper elementary and middle school science classrooms. This study is guided by the following research question: How do teachers' beliefs about teaching and learning change through participation in a long-term professional development in engineering design-based STEM integration?

The results of this study provide evidence that long-term professional development can help change teachers' beliefs about teaching practices which in turn may provide the background needed to help teachers believe they can integrate engineering meaningfully in their classrooms. Engineering integration can help both experienced and beginning teachers change their beliefs toward a student-centered view of instruction.

\section{Literature review}

Beliefs are personal episodic constructs that include affective and evaluative components [1]. Teachers' beliefs about teaching and learning represent a "conceptual map for instructional decision making" [2, pp. 86] and are reflected in their practices (e.g., [1], [3]-[4]). Current literature supports that teachers' beliefs are firmly held and hard to change (e.g., [5], [6]). It is particularly challenging for experienced teachers to shift toward student-centered beliefs because their views have been established, whereas newer teachers are more receptive to student-centered classrooms [7]. A study by Luft [7] found that professional development for fourteen secondary science teachers on inquiry based practices have varying levels of impact. Although experienced teachers altered their teaching practices, their beliefs remained unchanged. In contrast, novice teachers only changed their beliefs. As suggested by Luft, experienced teachers may alter their views on pedagogical strategies, student learning, or inquiry instruction through continued participation in professional development activities.

Other studies also describe the difficulties for teachers to change their beliefs, even with support from professional development programs. For example, Yerrick, Parke, and Nugent [8] explored this change in beliefs, and found that only a few experienced teachers' beliefs evolved from teacher-centered to student-centered beliefs after participation a two-week professional development program and claim that these changes were difficult to achieve. The authors attribute this difficulty in achieving deep-rooted change due to a variety of reasons; for example, mandated curriculum, strict accountability on teachers, and rigorous and required state 
assessments inform this teacher-centric belief and teaching practices. To learn how to overcome these barriers, teachers need extensive support. Therefore, this brief, short-term professional development program resulted in only a few positive changes in the teacher's beliefs, but the authors highlight how these changes are difficult to achieve in a short-term program. With extensive, longitudinal, sustained support, teacher participation in a professional development programs may lead to a more transformational shift in teacher beliefs, which translate to a shift in teaching practices to a more student-centric style.

While investigating the beliefs of six teachers who participated in summer workshops, Wallace and Kang [9] noted that their language about beliefs could be grouped into two competing categories. The first belief set regards students, efficiency, rigor, and exam preparation and tends to hinder the teacher's implementation of inquiry-based activities. These beliefs are more public and related to extrinsic influences or pressures that come from cultural, institutional, or policy motivated expectations for teachers. The second set of beliefs, which are more personal and less influenced by outside factors, relate to teachers' beliefs about the importance of inquiry and their interest in its use. The second belief set promotes the implementation of inquiry-based activities. The authors suggest that, although the second belief set influences how teachers view successful education, the first belief set is more likely to influence what the teachers decide to do. Wallace and Kang [9] also note a lack of policy language which supports the second set of beliefs. Yerrick, Parke, and Nugent [8] highlight similar contextual factors which influence the difficulty teachers have practicing what they believe. However, studies have also shown that in-depth, long-term professional development and research experiences are more likely to help teachers shift their beliefs in a student-centered direction [4], [10].

\section{Description of professional development}

This research is a part of a larger, 5-year study conducted to understand approaches to engineering integration in science curricula and classes. The research takes place within an National Science Foundation funded project in which approximately 200 teachers of science in grades 4-8 participate in develop engineering-based STEM integration curricular units for implementation in their classrooms and later to be published online. Each summer, 50 teachers participate in a 3-week summer institute and then receive support through coaching and mentoring during the subsequent academic school year. In the summer workshops, teachers explore engineering design and engineering practices through completing a variety of activities. An engineering education faculty member and an engineering faculty member lead this first week to help teachers increase their understanding about engineering design and engineering practices. Teachers also explore a variety of science concepts through engaging in engineering activities. Three science content area sessions are offered, and teachers choose one area to focus on: physical science, life sciences, and earth science. These sessions are led by science education faculty members and engineering faculty members. Finally, teachers learn about designing engineering design-based science units and design unit in teams to implement during the subsequent school year. 


\section{Methods}

This study is a pre-post interview study conducted with 64 th-8th grade teachers who participated in three consecutive years of intense professional development on engineering design-based STEM integration. We used a qualitative, holistic, multicase methodology [11] to investigate our research questions regarding how teachers beliefs about teaching in an integrated STEM setting have changed over the course of their three-year professional development experience. Each of the 6 teachers in this study represents an individual case and cross-case comparisons were made to aid in interpretation. Because beliefs cannot be directly observed, this methodology is appropriate because we must infer what beliefs are held by spoken words, actions, and intentions [5].

\section{Setting and participants}

The six teachers in this study were chosen from among 88 unique participants of the curriculum writing portion of the EngrTEAMS: Engineering to Transform the Education of Analysis, Measurement, and Science Project. There were nine teachers that participated in all three years. Of these nine, seven had pre-interview data. These seven were invited to participate in the follow-up interview. Six of the seven responded to our request for an interview. Table 1 provides an overview of the teachers' demographics. Pseudonyms have been used to preserve the identity of the teachers. 
Table 1 Participant Background

\begin{tabular}{|c|c|c|c|c|c|}
\hline Teacher & Degree & $\begin{array}{c}\text { Years of } \\
\text { experience* }\end{array}$ & $\begin{array}{c}\text { Grade(s) } \\
\text { taught }\end{array}$ & $\begin{array}{c}\text { Teaching } \\
\text { assignment }\end{array}$ & School information** \\
\hline Allison & $\begin{array}{l}\text { Secondary } \\
\text { Science Ed - } \\
\text { Life Science }\end{array}$ & 1 & $5^{\text {th }}-6^{\text {th }}$ grade & $\begin{array}{l}\text { General } \\
\text { Science }\end{array}$ & $\begin{array}{l}\text { City: Large } \\
\quad \text { Title } 1 \\
\text { SoC: } 91.8 \% \\
\text { FRL: } 81.8 \% \\
\text { ELL: } 32.3 \%\end{array}$ \\
\hline Ben & $\begin{array}{l}\text { Secondary } \\
\text { Science Ed - } \\
\text { Life Science }\end{array}$ & 3 & Middle school & Life Science & $\begin{array}{c}\text { Suburban: Large } \\
\text { SoC: } 26.6 \% \\
\text { FRL: } 8.4 \% \\
\text { ELL: } 5.2 \%\end{array}$ \\
\hline Holly & $\begin{array}{c}\text { Elementary } \\
\text { Ed. }\end{array}$ & 1 & K- $6^{\text {th }}$ grade & $\begin{array}{c}\text { Science } \\
\text { Specialist }\end{array}$ & $\begin{array}{c}\text { City: Large } \\
\text { Magnet \& Title } 1 \\
\text { SoC: } 96.4 \% \\
\text { FRL: } 88.2 \% \\
\text { ELL: } 32.3 \%\end{array}$ \\
\hline Mitchell & $\begin{array}{c}\text { Elementary } \\
\text { Ed. }\end{array}$ & 4 & $\mathrm{~K}-5^{\text {th }}$ grade & $\begin{array}{c}\text { STEM } \\
\text { Specialist }\end{array}$ & $\begin{array}{c}\text { Suburban: Large } \\
\text { Title } 1 \\
\text { SoC: } 61.4 \% \\
\text { FRL: } 59.5 \% \\
\text { ELL: } 10.5 \%\end{array}$ \\
\hline Penelope & $\begin{array}{c}\text { Elementary } \\
\text { Ed. }\end{array}$ & 4 & $\mathrm{~K}-5^{\text {th }}$ grade & $\begin{array}{c}\text { STEM } \\
\text { Specialist }\end{array}$ & $\begin{array}{c}\text { Suburban: Large } \\
\text { Title } 1 \\
\text { SoC: } 63.7 \% \\
\text { FRL: } 58.4 \% \\
\text { ELL: } 10.5 \%\end{array}$ \\
\hline Theodore & $\begin{array}{c}\text { Elementary } \\
\text { Ed. }\end{array}$ & 3 & $5^{\text {th }}$ grade & $\begin{array}{l}\text { General } \\
\text { Science }\end{array}$ & $\begin{array}{l}\text { City: Large } \\
\quad \text { Title } 1 \\
\text { SoC: } 98.6 \% \\
\text { FRL: } 94.8 \% \\
\text { ELL: } 32.3 \%\end{array}$ \\
\hline
\end{tabular}

*At beginning of project

**SoC: Students of Color (school); FRL: Free and Reduced Lunch Price (school); ELL: English Language Learners (district)

\section{Data collection}

Data for the study were collected using four questions from the semi-structured Teaching Beliefs Interview (TBI), which contained open-ended questions modified from an earlier study on high school science teacher beliefs [12]. Two TBIs were administered throughout the three-year study. These questions were designed to capture the participants' beliefs on student learning, how to assess student understanding, and instructional practices regarding pace and how they viewed their role in the classroom. The TBI interview questions related to beliefs are:

1. How do you describe your role as a teacher? (Teaching practice)

2. How do your students learn best? (Student learning)

3. How do you decide when to move on to a new topic in your class? (Assessment)

4. How do you maximize student learning in your classroom? (Teaching practice) 


\section{Data analysis}

The interviews were transcribed and coded using existing rubrics developed from two previous studies $[13,14]$. The rubrics are organized into 5 levels of responses on a continuum from teacher-centered beliefs to student-centered beliefs. We categorized the levels as: teacher leads students absorb, teacher leads - students do, teacher lead - students experience, teacher guides students experience, students guide - students experience. For an example, the rubric for the question "How do you maximize student learning?" consists of a description for each level and examples of possible responses. Figure 1 provides a truncated version of this rubric.

\section{How do you maximize student learning?}

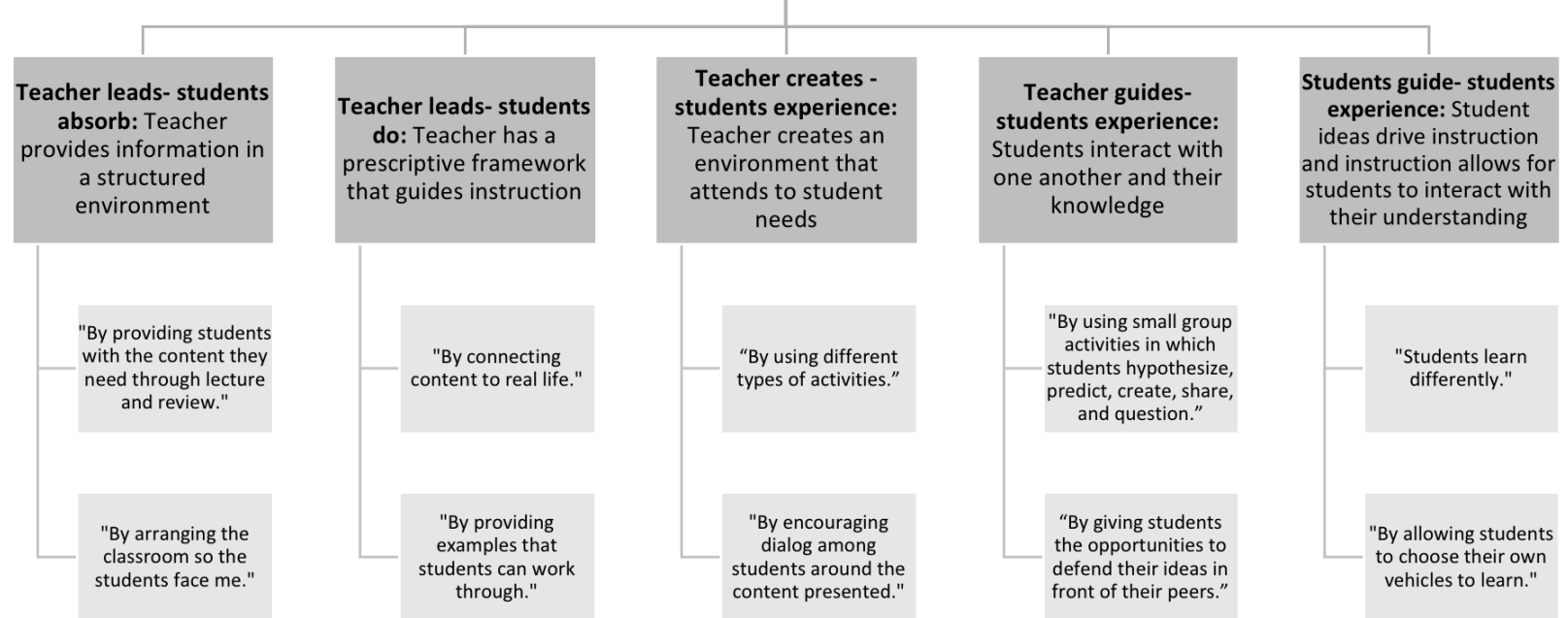

Figure 1 A truncated version of the rubric for coding question 4 for the modified TBI in this study

Each question on the pre- and post-interviews was coded holistically as the unit of analysis, i.e., one code was given per answer to each question asked. As a research team, we trained on the use of the rubrics calibrating with experts on the rubrics. After establishing coding calibration, each question was assigned to 2 researchers. If agreement was perfect, the codes were set. When there were disagreements in codes, the whole group discussed and came to consensus. Next, each participant's case was written by comparing their pre-post answers for each question and then considering the answers for each participant as a whole from pre to post. Each case provides insight into the teachers' change in beliefs over participation in the professional development program. Then cases were compared and contrasted in order to identify trends among the participants as well as the changes in their overall beliefs over time.

\section{Results and discussion}

In this section, we will summarize the beliefs of the teachers to explore shifts in their beliefs. Then, we will present each teacher's case by describing the beliefs captured in baseline and post interviews. Finally, we will provide a summary of the results to answer the research questions. 


\section{Change of teachers' beliefs}

Table 2 summarizes each teachers' beliefs based on their interview responses. Each response to one of the 4 interview questions is marked with an asterisk. The teachers as a whole shifted their beliefs from more teacher focused to more student focused over the course of the project. The following sections describe each teacher's case and in what manner shifts occurred.

Table 2 Change in Participants' Beliefs

\begin{tabular}{|c|c|c|c|c|c|c|}
\hline & & $\begin{array}{l}\text { Teacher led- } \\
\text { students } \\
\text { absorb }\end{array}$ & $\begin{array}{l}\text { Teacher led - } \\
\text { students do }\end{array}$ & $\begin{array}{c}\text { Teacher led - } \\
\text { students } \\
\text { experience }\end{array}$ & $\begin{array}{l}\text { Teacher } \\
\text { guided - } \\
\text { students } \\
\text { experience }\end{array}$ & $\begin{array}{c}\text { Student } \\
\text { guided - } \\
\text { student } \\
\text { experience }\end{array}$ \\
\hline \multirow[t]{2}{*}{ Allison } & Baseline interview & * & * & * & * & \\
\hline & Post interview & & & $* *$ & $* *$ & \\
\hline \multirow[t]{2}{*}{ Ben } & Baseline interview & $* *$ & $*$ & $*$ & & \\
\hline & Post interview & $*$ & & $* *$ & & * \\
\hline \multirow[t]{2}{*}{ Holly } & Baseline interview & $* * *$ & & * & & \\
\hline & Post interview & & & $* * *$ & $*$ & \\
\hline \multirow[t]{2}{*}{ Mitchell } & Baseline interview & $*$ & $*$ & $*$ & $*$ & \\
\hline & Post interview & & $* *$ & $*$ & $*$ & \\
\hline \multirow[t]{2}{*}{ Penelope } & Baseline interview & $* *$ & & $* *$ & & \\
\hline & Post interview $^{+}$ & & $* *$ & $*$ & & \\
\hline \multirow[t]{2}{*}{ Theodore } & Baseline interview & & $*$ & $* * *$ & & \\
\hline & Post interview & & ** & * & & * \\
\hline
\end{tabular}

Note. Each asterisk represents the answer to one of the four questions from the Teacher Belief Inventory. The table visualizes the change in the participants' belief systems prior and after participation in the professional development program. ${ }^{+}$For this teacher, one of the items could not be coded due to her answer not addressing the real meaning of question, and therefore, is not included in the table.

\section{Allison}

Throughout several years of professional development, Allison's beliefs about her role as an instructor, how students learn best, and how to maximize student learning shifted, while she remained at the same level regarding how she decided when to move on to a new topic in her classroom teaching. In her pre-interview, Allison indicated that she was a traditional instructor. After stating, "I have to turn in my lesson plans on a weekly basis at the beginning of the week," she expressed her belief that following the lesson plans enabled her to think about different parts of the lesson and provided a beginning and an ending of the lesson to give it closure. This statement provided evidence of how she viewed her role as a curriculum planner for her students. After attending the long-term professional development, she demonstrated a major change in her beliefs about her role as facilitator of group discussions. She stated, "[Students] do a lot of work together with their group, so I just monitor them and give them expectations, guidelines, and assignments." This comment demonstrated that she was now focusing more on student-centered activities and viewing her role as that of a facilitator (Teacher led - students experience). 
In both interviews, Allison explained that students learn best through hands-on activities while listening to the teacher during lab activities in which they are building things, indicating a more teacher-centered view. In the post interview, however, she stated that students learn best not only through hands-on activities, but also by applying what they learn to real-life situations, meaning that the teacher provides instruction and students themselves apply their knowledge into applicable contexts. This suggests a transition towards a more student-centered belief.

At the beginning of the study, Allison described the variety of learning activities that her students engaged in, such as carrying out lab activities, discussing with each other, and reading material relevant to what they were learning (Teacher led - students experience). She believed that engaging in activities instead of just sitting and listening to the teacher was important for students to maximize their learning. After the professional development program, her beliefs had aligned to more constructivist teaching approach. Allison now believed the best way for students to maximize their learning was to engage in more hands-on activities and more groups work because these opportunities helped students to learn from each other (Teacher guided students experience). Allison's beliefs about student assessment remained constant throughout the study. In both interviews, she relied on giving different kinds of assessments during and at the end of a unit to see where students were. She expressed that formative assessments are constructive ways to see whether her students understood the topic well enough to move on.

Ben

Over the course of the project Ben had several areas of growth in his attitudes, while other areas remained constant. During the start of this study, he described his role as a teacher in more of a traditional view, meaning that he delivered knowledge and curricular instruction to his students (i.e., students meeting standards, learning content). After several years participating in this program, Ben evolved his role to be more of a guide to his students. In this view, he focuses on the relationship built between the teacher and student, guiding students to develop the skills needed to answer questions and think critically. In his post-interview, Ben claims, "[I] make sure that every kid that is in my classes is meeting proficiency on all of those standards. And then also to be a good role model, and to help build just daily skills for the kids, whether it be social skills, or organizational skills, or just character type traits." While Ben still focuses attention on making sure students are proficient in the content, he adds an additional component of being a mentor and a guide to his students, meaning that he leads students to have their own learning experiences.

In a similar manner, Ben also evolved in his attitudes on when to move on to new topics in his classroom. At the beginning of the project, Ben provided a more instructive approach in his teachings, meaning that he directed student learning, and moved on when he felt students understood the content (such as through formative assessments). After several years, his attitudes on this topic morphed into a more student-centric approach. He describes how he still employs formative assessments but focuses on the discussions held by students working in groups. He states, "If every group is held accountable, let's say they're working in groups, then you don't really move on until every group has shared, until every group has done their part... So, it's more for me about discussion, observation, and just seeing what the kids can produce, not how they can respond to some questions." In this quote, Ben adopts a more student-guided and student- 
experience approach as he decides when to move on to a new topic, meaning that the decisions are based on how students perform in their groups, demonstrating understanding through their conversations and interactions held with their peers.

There were two areas where Ben reflected no change in his attitudes after participation in the professional development program. When asked how his students learn best, Ben's attitudes reflect a teacher led-student guided attitude, meaning that students apply knowledge acquired from the teacher. Ben's attitudes also remained the same when asked how to maximize student learning. In this view, his attitude reflects more of a traditional set of beliefs, meaning the teacher provides information in a structured manner (i.e., PowerPoint presentations, tests...). This teacher led-students absorb attitude remained throughout the professional development program.

\section{Holly}

We observed a shift in Holly's views of her students and of her own teaching, from a more teacher-focused view to a more student-focused one (Table 2). The most apparent shift was in her view of her role as a teacher. In the baseline interview, she expressed her role as a teacher was to "share my knowledge with my students" and "[give] them the knowledge of my content." After participation in the long-term PD, Holly expressed her role to be more of a collaborator, showing characteristics of a student-centered approach to her teaching. In the post-interview, she expressed her role as someone who "help[s] give [students] the tools and skills they need in order to grow in their learning... equipping them with what they need to be successful." Holly further elaborated, saying that she is there to "[teach] them what to get and how to get it, or where to find [their] answers." Here we observe a shift in Holly's belief in who is in charge of students' learning. In the baseline interview, her role is focused on a unidirectional transmission of content knowledge, whereas in the post-interview, she serves as a mediator to help guide students in their learning.

No change was observed in Holly's beliefs regarding student learning ("Teacher led-students experience" for baseline and post-interview), but there was a noticeable shift in assessment- and teaching practice-related beliefs (from "Teacher led-students absorb" to "Teacher led-students experience" for both categories). When asked how she decided to move on to a new topic in her class, Holly emphasized her reliance on the course outline and did not mention her students. In her post-interview, Holly expressed her reliance on some form of student feedback to judge whether to move on. She elaborated that she makes some effort to help students that have not demonstrated mastery over the subject. With respect to teaching related beliefs, her baseline interview reflected a teacher-centered views. She attributed student learning to having a structured environment, free of distractions to maximize her students' learning. In the postinterview, Holly expressed her ability to maximize student learning is informed by her students' abilities and understandings. She states that the students are "getting work at the level that they can be successful at...Then, when they're working with me, we take it up one level higher so that they get the necessary support that they need to move to that next level." Holly highlights her role as someone who creates an environment that is informed by students' needs. Taken together, we observe substantial growth toward a more student-centered approach from Holly. 


\section{Mitchell}

Mitchell pre- and post- interviews indicate that he did not experience quite as much change as the other participants. How he views his role as a teacher, how is students learn best, and how his student's learning is maximized remained the same, whereas, how Mitchell determines when he should move on to a new topic did evolve. When describing his role as a teacher during the postinterview, Mitchell tended to focus on the outcomes that he generates for his students, saying that his "role as a teacher is to develop [his] students to their fullest abilities." This tenor, which persisted from the pre-interview, suggests a more teacher-focused approach.

Based on his interviews - although there was no change observed in the nature of his responses-Mitchell expressed either transitional or constructivist views on how to maximize learning or how his students learn best. When discussing how to maximize learning Mitchell suggests that he tries "to get them [the students] actively engaged in... their projects and with each other." He focuses on activities and working in groups. This is indicative of a teacher whose practices are transitional between teacher-focused and constructivist approaches. When talking about how his students learn best he expressed the importance of students constructing their knowledge through working on teams together and discussing things with each other. Mitchell suggested that his students learn best by "Learning to listen to each other, collaborate, and [learning] how to recognize that other people can provide real help in their learning." These views indicate constructivist thoughts on learning.

Although the other parameters remained consistent, Mitchell's expressions regarding how he decides to move on to a new topic did evolve from an approach based on structure and time to one motivated, in part, by student understanding. In the post interview, he suggests that "as the kids are working in their groups and at their engineering team tables, [he] observe[s] what they're doing." But then he augments this with recognition of the constraints of time, which had been his primary focus in the pre-interview. One possible explanation for has relative lack of change, as interpreted from his pre- and post- interviews, and as compared to the other participants, is that he began the study with more experience than other participants.

\section{Penelope}

During the study, Penelope experienced a rather diverse set of evolution across the metrics. One of Penelope's responses about her role as a teacher was not able to be coded due to her answer describing the responsibilities of her job rather than her beliefs about her role as a teacher. From her pre-interview, it was determined that she was very teacher focused, with an emphasis on the impartation of knowledge. Unfortunately, we did not have enough data in her post-interview to determine whether any evolution had occurred. When discussing how her students learn best, in both the pre- and post- interviews, Penelope expressed views consistent with transitional practices that have elements of being teacher focused but also constructivist. In both interviews, she primarily suggests that her students learn best through doing. As noted in the pre-interview, her students learn "by hands on activities_-by doing, exploring, discovering..." That being said, she did show hints of more constructivist ideas by noting the importance of her students discussing the ideas with each other to help them form their understanding. 
Surprisingly, when comparing pre- and post- interview responses regarding when to move on to a new topic, Penelope actually regressed along our scale from focusing more on student feedback to reliance on her established structure, curriculum, and time constraints. She suggested that "the curriculum kind of dictates it for [her]." This may be due to experience. It is possible that as a teacher gains experience with how long it typically takes a certain demographic to gain understanding on a topic, they use more effective curriculum planning and do not feel the need for as much reliance on student feedback.

Lastly, when talking about how to maximize student learning, initially (pre-interview), her main focus was on structure and making her students aware of her plans for the class, with the ultimate goal of motivating them. Referencing her students, she would often begin by telling them "what [she] expect[s]... or the objective is what [she is] teaching [them] today." We felt that it was very teacher focused. However, in the post interview, she expressed a focus on how much her students need to experience the material. She opened by suggesting that she maximizes her student's learning "by giving opportunities for them to practice a lot." We felt as though she had made progress during the course of the study.

\section{Theodore}

The area of greatest change that Theodore displayed was related to his ideas for the question "how do your students learn best?" In his pre-interview, Theodore's statements indicate that he believes students learn best by learning a topic and applying it through a hands-on activity. He "tr[ies] to incorporate that [hands-on activities] whenever I can in science, but it can be hard sometimes depending on what you're teaching". Here he indicated that he thinks that students learn best when they are given an appropriate activity by their teacher and that it is the teacher's responsibility to develop that activity. In his post-interview, he demonstrated a much more student-centered approach. He states that "students learn best, I believe, by feeling a connection to what they're learning, and kind of learning in an authentic way", such as when they are "able to kind of ask their own questions about that topic, maybe do some research about that topic, maybe try and, if possible, maybe build a model or a representation, or do something to experience the topic, rather than just kind of talk about it". He is focused on what the students are doing and how they are learning without mentioning the teacher at all. In his post-interview belief, the students are responsible for asking the questions and finding the information without being told by the teacher.

Theodore described similar beliefs in the pre and post-interviews around the question "how do you describe your role as a teacher?" In both instances, Theodore describes his role in a teacher centered manner that focuses on how he as the teacher provides opportunities for the students to learn. For example, in the pre-interview, he stated "my primary role is to teach the 6th grade standards for science and writing, but also [act as] a mentor person as well for students". In the post-interview, he again indicated his role as the leader of the learning responsible for giving students things to do with the statement "I guess my role as a teacher, would be to help integrate authentic kind of problem solving, and hands on learning as much as possible into the school day". Although he is focused on hands-on learning, he talks about it in a teacher centered manner. Theodore also described similar before and after beliefs around the question "how do you maximize student learning?" In the pre-interview, he started his description with "I try to 
maximize student learning by giving multiple opportunities, like, multiple ways of learning about a concept" and in the post-interview he started with "I try to hit different topics in a few different ways". In both instances, he allocated on what he meant by describing example of different ways of learning that he employs. These views demonstrate that he is considering a range of student needs, but his classroom is teacher centered in that he is the one choosing when and how to use certain activities to maximize student learning.

Theodore moved away from a student-centered approach over the time period for his beliefs about how to move on to a new topic. In the pre-interview, his beliefs were based on several sources of student feedback, such as "different labs, maybe different group activities, and then there's a post-test at the end." Additionally, he stated that "if there's something standing up that a lot of students don't get then we'll go back and hit that again." However, in the post interview, he stated that "we kind of set a tentative time limit" based on "pacing guides and schedules" but the time limit is mostly based on how long it takes students to complete activities, rather than on their understandings.

\section{Cross-case summary of the results}

In the present study, we explored teachers' attitudes before and after a long-term and extensive professional development program. Our results indicate that teachers overall had moderate shifts toward student-centered beliefs while involved in this professional development. These shifts may have been due to participation in this professional development, but there are many other factors that may have been involved as well. It is likely a combination of factors such as participation in this PD program, increased experience with standards that require studentcentered practices, and/or participation in professional learning communities.

All teachers other than Penelope made overall shifts toward student-centered beliefs. The two teachers that had just finished their first year of teaching at the beginning of this program, Allison and Holly, made large shifts toward student-centered beliefs. Allison's shifts were weighted toward beliefs regarding teaching practices; whereas, Holly's shifts were more even across the four questions. Ben, a third-year teacher at the start of this study, also make large shifts toward student-centered beliefs. His shifts were in his beliefs regarding teaching practice and assessment - but he remained stable in beliefs regarding student learning. Mitchell, Penelope, and Theodore did not shift substantially overall.

Our findings are consistent with previous literature in that more experienced teachers' beliefs were more stable [7, 8]. While the more experienced teachers (Mitchell and Penelope) may have changed, they did not change to the same magnitude as the newer teachers. In contrast, new teachers (Holly and Allison) demonstrated greater change towards a more student-centered belief from baseline- to post-interview. This suggests that with extensive support, newer teachers may demonstrate a significant shift in their attitudes towards student-centered teaching and teaching practices [8]. Furthermore, this research adds to the literature on beliefs of science teachers as teachers' beliefs were similar to other findings even though the treatment was integrated science and engineering. 
As a whole, the teachers made shifts toward student-centered beliefs in each of the four areas (role of the teacher, how students learn best, when to move on, and how to maximize learning). We saw the most growth in the area of the role of the teacher. However, this was due to major shifts of three teachers (at least 2 levels for the two brand new teachers [Allison and Holly] and one of the teachers with 3 years of experience [Ben]); the other three teachers did not shift (or in Penelope's case, did not answer the question posed). The PD focused a lot on how to implement the curriculum, which may have had an impact on the way these early career teachers looked at their role in the classroom.

The remaining questions saw less shift but had some interesting findings. For the question regarding how student learn best, we saw only two teachers make a shift in this area, with the other 4 holding constant. Again, this was one of our new teachers (Holly) and one of the teachers with 3 years of experience (Theodore). It is interesting to note that Theodore made a significant shift in this area from "teacher creates - students experience" to "students guide - students experience" which is a two-level shift. For the question regarding when to move on, we saw a mix of responses. Allison remained constant but at the more student-centered "teacher guided students experience" level. Ben made a three-level shift from the fairly teacher-centered "teacher leads - students do" level to the most student-centered "students guide - students experience" level. Holly went from the teacher-centered "teacher leads - student absorbs" level to the moderate "teacher leads - students experience" level, and Mitchell start from the most teachercentered view to a still teacher-centered "teacher leads - students experience" level. In this question, two of our teachers actually shifted toward teacher-centered beliefs in their responses. Both Penelope and Theodore went from the moderate "teacher leads - students experience" level to the "teacher leads - students do" level. Finally, with the question regarding how to maximize student learning, three teachers made a shift toward student-centered beliefs and three remained constant. Our two new teachers, Allison and Holly, shifted 1 and 2 levels respectively. Allison went from the moderate "teacher leads - students experience" level to a more student-centered "teacher guides - students experience", whereas Holly shifted from the most teacher centered to the moderate "“teacher leads - students experience" level. Penelope made a shift toward studentcentered on this question; however, her response went from the most teacher-centered to the "teacher leads - students do" level. This more detailed look at the shifts in teacher beliefs during the engineering PD again provide more evidence teachers shift toward a more student-centered approach [4], but that early career teachers' beliefs are more likely to shift more than teachers with more experience [7]-[8].

\section{Implications and future directions}

The professional development program provided a variety of opportunities for the teachers to reflect on their beliefs about teaching and learning. Engaging in activities that focus on engineering and science during the summer workshops allowed teachers to explore what their students experience as they participate in those activities in class. The results demonstrate that the participating teachers shifted some of their traditional, teacher-centered beliefs about teaching and learning towards more student-centered beliefs. As our data shows, it was not easy and quick process for the teachers to change their beliefs; however, benefits of this long-term, sustained professional development program were evident. While the PD did not focus specifically on teachers' beliefs, perhaps providing focused reflection time on what teachers 
believe about engineering and pedagogy and how this should impact their practice should be included in aid in their shifts toward student-centered teaching. Our results suggest the need for additional research on teachers' beliefs about teaching, learning, and their classroom practices around engineering and science instruction. This includes exploring teachers' learning and implementation of engineering and examining the effects this learning process has on teachers' teaching practices and students' science and engineering learning. Given the shifts seen in teaching practices beliefs, further studies will be conducted to investigate potential shifts in classroom practices.

\section{Acknowledgements}

This work is supported by the National Science Foundation under grant numbers NSF DRL1238140. Any opinions, findings, and conclusions or recommendations conveyed in this study are those of the authors and do not necessarily reflect the views of the National Science Foundation. 


\section{References}

[1] J. Nespor, "The role of beliefs in the practice of teaching," Journal of Curriculum Studies, vol. 19, no. 4, pp. 317-328, 1987.

[2] P. L. Grossman, The making of a teacher: Teacher knowledge and teacher education. New York: New York: Teachers College Press, Teachers College, Columbia University, 1990.

[3] M. Z. Hashweh, "Effects of science teachers' epistemological beliefs in teaching," Journal of Research in Science Teaching, vol. 33, no. 1, pp. 47-63, 1996.

[4] F. Savasci and D. F. Berlin, "Science teacher beliefs and classroom practice related to constructivism in different school settings," Journal of Science Teacher Education, vol. 23, no. 1, pp. 65-86, 2012.

[5] M. F. Pajares, "Teacher beliefs and educational research: Cleaning up a messy construct," Review of Educational Research, vol. 62, pp. 307-332, 1992.

[6] A. Lumpe, "Beliefs about teaching science: The relationship between elementary teachers' participation in professional development and student achievement," International Journal of Science Education, vol. 34, no. 2, pp. 153-167, 2012.

[7] J. A. Luft, "Changing inquiry practices and beliefs: The impact of an inquiry-based professional development programme on beginning and experienced secondary science teachers," International Journal of Science Education, vol. 23, no. 5, pp. 517-534, 2001/05/01 2001.

[8] R. Yerrick, H. Parke, and J. Nugent, "Struggling to promote deeply rooted change: The "filtering effect" of teachers' beliefs on understanding transformational views of teaching science," Science Education, vol. 81, no. 2, pp. 137-159, 1997.

[9] C. S. Wallace and N.-H. Kang, "An investigation of experienced secondary science teachers' beliefs about inquiry: An examination of competing belief sets," Journal of Research in Science Teaching, vol. 41, no. 9, pp. 936-960, 2004.

[10] P. Enderle et al., "Examining the influence of RETs on science teacher beliefs and practice," Science Education, vol. 98, no. 6, pp. 1077-1108, 2014.

[11] R. K. Yin, Case study research and applications: Design and methods, 6th ed. Los Angeles, CA: Sage, 2018.

[12] G. Roehrig and J. Luft, "Inquiry teaching in high school chemistry classrooms: The role of knowledge and beliefs," Journal of Chemical Education, vol. 81, no. 10, pp. 15101516, 2004.

[13] J. A. Luft, "Capturing science teachers' epistemological beliefs: The development of the Teacher Beliefs Interview," Electronic Journal of Science Education, vol. 11, no. 2, pp. 38-64, 2007.

[14] T. J. Moore et al., "Changes in faculty members' instructional beliefs while implementing model-eliciting activities," Journal of Engineering Education, vol. 104, no. 3, pp. 279$302,2015$. 